\title{
NOTES ON AMERICAN THERIDIID SPIDERS
}

\author{
By Herbert W. Levi
}

\section{Museum of Comparative Zoology, Harvard University}

\begin{abstract}
About 195 species of theridiid spiders are known from north of Mexico, about 800 in all the Americas. Among them are our commonest spiders but also numerous rare species. This is the first addition to my revisions of spiders of this family. Similar additions will be made periodically as it becomes necessary to report on new species, describe the other sex of species known from only males or females, record habitat notes of rare species and make corrections.

For their assistance I want to thank Miss M. E. Galiano of Buenos Aires, Mr. V. D. Roth of the Southwestern Research Station of the American Museum of Natural History, who collected specimens of rare Arizona species, and Dr. W. J. Gertsch, who made me aware of an error in my revision of the genus Tidarren and facilitated the loan of Latrodectus mactans hesperus. This research is in part supported by Public Health Research Grant AI-or 944 from the National Institute of Allergy and Infectious Diseases.
\end{abstract}

\section{Theridion arizonense Levi}

Figures I-4

Theridion arizonense Levi, 1957, Bull. Amer. Mus. Natur. Hist. 112: 49, figs. 137, 138, ㅇ. Female holotype from Rustler's Camp, Chiricahua Mountains, Cochise County, Arizona, in the American Museum of Natural History.

This species has heretofore only been known from the female.

Description of male. Carapace yellowish with a gray line around carapace and a wide median gray band. Sternum gray all around. Legs dusky gray, darker distally. Dorsum of abdomen gray with pairs of white spots posteriorly, sides yellowish, venter gray. Eyes subequal in size. Anterior median eyes one and one-quarter diameters apart, their radius from laterals. Posterior median eyes less than a diameter apart, one diameter from laterals. Total length, $2.2 \mathrm{~mm}$. Carapace, I.I $\mathrm{mm}$ long, I.O $\mathrm{mm}$ wide. First femur, $2.3 \mathrm{~mm}$; patella and tibia, $2.5 \mathrm{~mm}$; metatarsus, $2.3 \mathrm{~mm}$; tarsus, $0.8 \mathrm{~mm}$. Second patella and tibia, $1.6 \mathrm{~mm}$; third, $0.9 \mathrm{~mm}$; fourth, $1.5 \mathrm{~mm}$.

The embolus of the palpus (Fig. 4) appears to be partly covered by a lamella like that of $T$. lawrencei. The shape of the radix (Fig. 3) and ducts within the tegulum (Fig. 4) differ. 
Record. Arizona: Rustler's Camp, Chiricahua Mtns., Cochise Co., 24 June 1963, ô (D. Futuyma).

\section{Theridion cochise Levi}

Figures 5-8

Theridion cochise Levi, 1963, Bull. Mus. Comp. Zool., 129: 553, figs. 123, 124 $\hat{\delta}$. Male holotype from Southwestern Research Station, Portal, Cochise County, Arizona, in the American Museum of Natural History. This species has heretofore only been known from the male.

Description of female. Carapace, sternum and legs bright yellow.
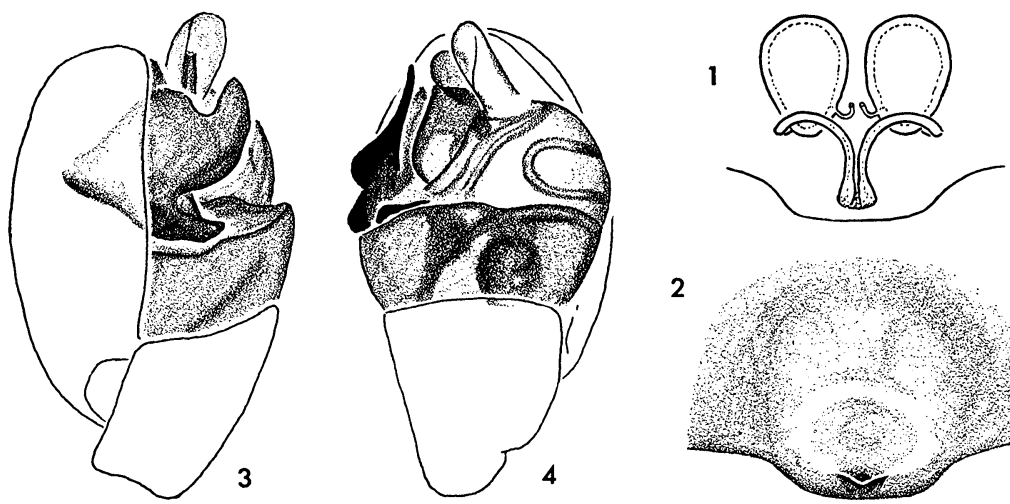

2
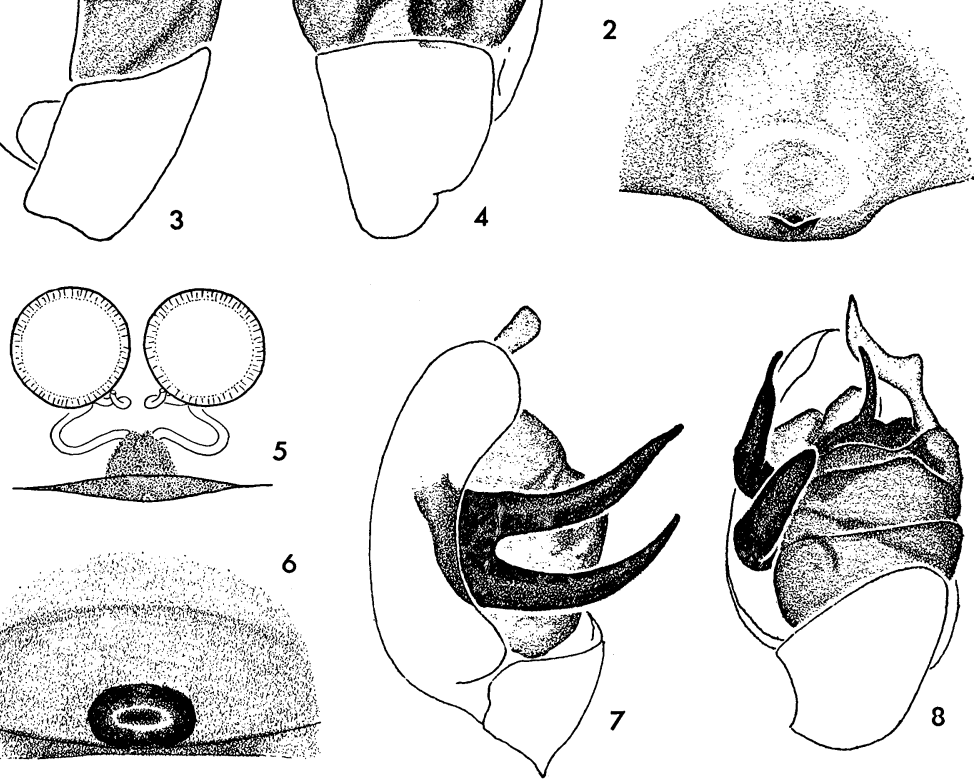

Figs. 1-4 Theridion arizonense Levi. 1. Female genitalia, dorsal view. 2. Epigynum. 3,4. Left palpus. 3. Mesal view. 4. Ventral view.

Figs. 5-8 Theridion cochise Levi. 5. Female genitalia, dorsal view. 6. Epigynum (from slightly posterior). 7,8. Left palpus. 7. Mesal view. 8. Ventral view. 
Abdomen whitish with some indistinct gray dorsal spots. Anterior median eyes one diameter apart, less than one diameter from laterals. Posterior median eyes one diameter apart, one and one-half diameters from laterals. Total length, $3.8 \mathrm{~mm}$. Carapace, I.4 mm long, I. 35 $\mathrm{mm}$ wide. First patella and tibia missing; second, $2.3 \mathrm{~mm}$; third, I.7 $\mathrm{mm}$; fourth, $2.5 \mathrm{~mm}$.

The epigynum (Fig. 6) is similar to that of Theridion morulum O.P.-Cambridge, but the dark area and openings are smaller. The opening is in the center of a dark depression.

Record. Arizona: Cochise County, South Fork, I3 July 1963, 우 (V. Roth).

\section{Theridion myersi Levi}

Theridion myersi Levi, 1957, Bull. Amer. Mus. Natur. Hist. 112: 31, figs. 95-98, 우 $\hat{o}$. Male holotype from Fort Myers, Lee Co., Florida, in the American Museum of Natural History.

This rare species was known only from Florida; Monterrey, Nueva León; Tamaulipas and Ixtepex, Oaxaca, Mexico, without information about its habitat. I collected an adult male under coral stones on the side of the highway. I8.III.1964, on Bahia Honda Key, Monroe Co., Florida.

\section{Theridion melanosternum Mello-Leitão, emend.*}

Figures 9-12

Theridion melanosternon Mello-Leitão, 1947, Arq. Mus. Paranaense 4: 237, figs. 4, 5 o. Female holotype from Bariquí, Curitiba, Brazil in the Inst. Defeso do Patrimonio Natural in Curitiba, examined by $M$. E. Galiano in 1968.

The types of the species were deposited in the Museu Paranaense. The museum no longer exists and the specimens are now kept in the Instituto de Defeso do Patrimonio Natural, Secretaria de Est. dos Negocios da Agricultura, Curitiba, Paraná, Brazil. It was never possible for me to examine the specimen. Miss Maria Elena Galiano paid a visit to this institution and made drawings for me of the type of Theridion melanosternum. The specimen is labeled Theridium nigristerni. Mello-Leitão gave total length $3.6 \mathrm{~mm}$, and first patella and tibia $4.7 \mathrm{~mm}$. The long legs and epigynum (Fig. IO-I I) resemble those of Theridion longipedatum Roewer ( $=T$. longipes Keyserling), described from Santa Fé de Bogota (a locality where the specimen presumably was bought or traded and not where it was found). However the measurements Keyserling gives are total length, $5.3 \mathrm{~mm}$ and first patella and tibia, $5.2 \mathrm{~mm}$.

*The specific name is here emended to have a correctly latinized ending, 


\section{Tidarren haemorrhoidale (Bertkau)}

Theridium haemorrhoidale Bertkau, 1880, Mém. Cour. Acad. Roy. Sci. Lett. Belgique 43: 78. Female holotype from Rio de Janeiro, lost. The description fits the widespread species believed to occur from the southern United States to Argentina and Chile.

2Theridion maculosum Keyserling, 1884, Die Spinnen Amerikas 2(1): 30, pl. 1, fig. 14 \%. Female holotype from Venezuela ["Caracas" on specimen], in the Institut Royal des Sciences Naturelles de Belgique, Brussels; examined, but in very poor physical condition.

Theridium elevatum Banks, 1897, Canadian Entomol. 29: 195. Female holotype from Brazos County, Texas, in the Museum of Comparative Zoology; examined. Name preoccupied by $T$. elevatum Thorell 1881.

Theridium fordulum Banks, 1909, Proc. Acad. Natur. Sci. Philadelphia 61: 203. Female holotype from Chiral Paraíso, Costa Rica, in the Museum of Comparative Zoology; examined.

Theridium texanum Banks, 1910, Bull. U.S. Natl. Mus. 72: 20. New name for $T$. elevatum Banks.

Theridion minor Chamberlin and Ivie, 1934, Bull. Univ. Utah, Biol. Ser. 2(4): 10, 24-25, ․ Female holotype from Tallahassee, Leon Co., Florida, in the collection of the University of Utah.

Tidarren fordum:-Levi, 1956, J. New York Entomol. Soc. 63: 73, figs. 49-57, 61-64, \&, ô, map. 1967, Bull. Mus. Comp. Zool. 136: 28, map. Not Theridion fordum Keyserling.
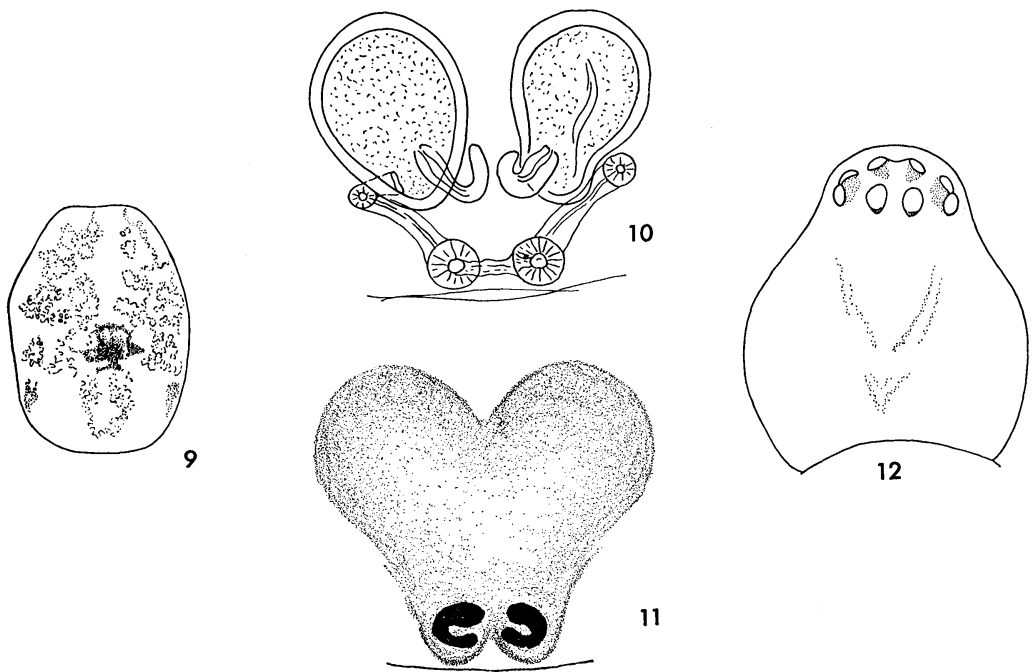

Figs. 9-12 Theridion melanosternum Mello-Leitão. 9. Abdomen. 10. Female genitalia, dorsal view. 11. Epigynum. 12. Carapace. $(9,10$, 12 illustrated by M. E. Galiano, 11 after Mello-Leitao.) 
Note. Recently I indicated that I had examined the type of Theridion fordum Keyserling (Levi, I967, Bull. Mus. Comp. Zool. 136: 28). This was not the case. Dr. W. J. Gertsch first made me aware that the type might not be the species I thought. Through the courtesy of Dr. J. G. Sheals and Mr. D. Clark the specimens were examined. Keyserling indicated that the specimen described came from Bogota, but that specimens from other parts of South America were at hand. The vial from Bogota contained two specimens: a mature female clearly belonging to $T$. sisyphoides (Walckenaer) and a juvenile specimen belonging to the other species for which the name $T$. haemorrhoidale is now used. The mature female was designated lectotype of $T$. fordum. The name Theridion fordum thus becomes a synonym of $T$. sisyphoides. All other specimens labelled by Keyserling as $T$. fordum belong to $T$. haemorrhoidale. The possibility exists that $T$. haemorrhoidale is a group of species having a similar epigynum. Particularly North American specimens are quite variable. However there are few males in collections and the females do not readily fall into groups. All intergradations occur.

\section{Latrodectus variolus Walckenaer}

Latrodectus variolus Walckenaer, 1837, Histoire Naturelle des Insectes Aptères, 1: 648. Female lectotype is Abbot manuscript figure 391, in the British Museum (Natural History) library. - McCrone and Levi, 1964, Psyche 71: 13.

Latrodectus mactans hesperus Chamberlin and Ivie, 1935, Bull. Univ. Utah, Biol. Ser. 3 (1) : 15. Figs. 1, 4, 6-14, 21, 22-23, 우, ㅎ․ Female holotype and male paratype from Salt Lake City, in the Univ. Utah collection now kept at the American Museum of Natural History; examined. NEW SYNONYMY.

Latrodectus curacaviensis:-Levi, 1959. Trans. Amer. Microscop. Soc. 78 : 38 (in part).

In a recent paper Kaston (1968, Entomol. News 79: I13) indicated that he considered $L$. hesperus different from L. mactans and $L$. variolus but gave no evidence for this statement. He indicated "that at least the common black widow of the west must be called hesperus." There is no indication whether he refers to the northern one common in British Columbia to northern California and considered Latrodectus variolus, or the one of southern California believed to be Latrodectus mactans.

The type of $L$. m. hesperus, was unavailable to me in 1957. I have recently examined both the female holotype and male paratype and have found them to be $L$. variolus. The female has a complete, unbroken "hourglass" on her venter. The name had previously been synonymized with L. mactans (Levi, 1959). 
That the western form of $L$. variolus is the same as that of the east and southeast has to be assumed until we have contrary evidence based on modern species concepts. Such evidence might be significant morphological difference combined with differences in habits without intermediates by two populations separated geographically indicating reproductive isolation. This has not been found. Or better evidence might be the presence of two allopatric species with a region of overlap, in which two noninterbreeding populations can be found side by side. This also has not yet been demonstrated. 

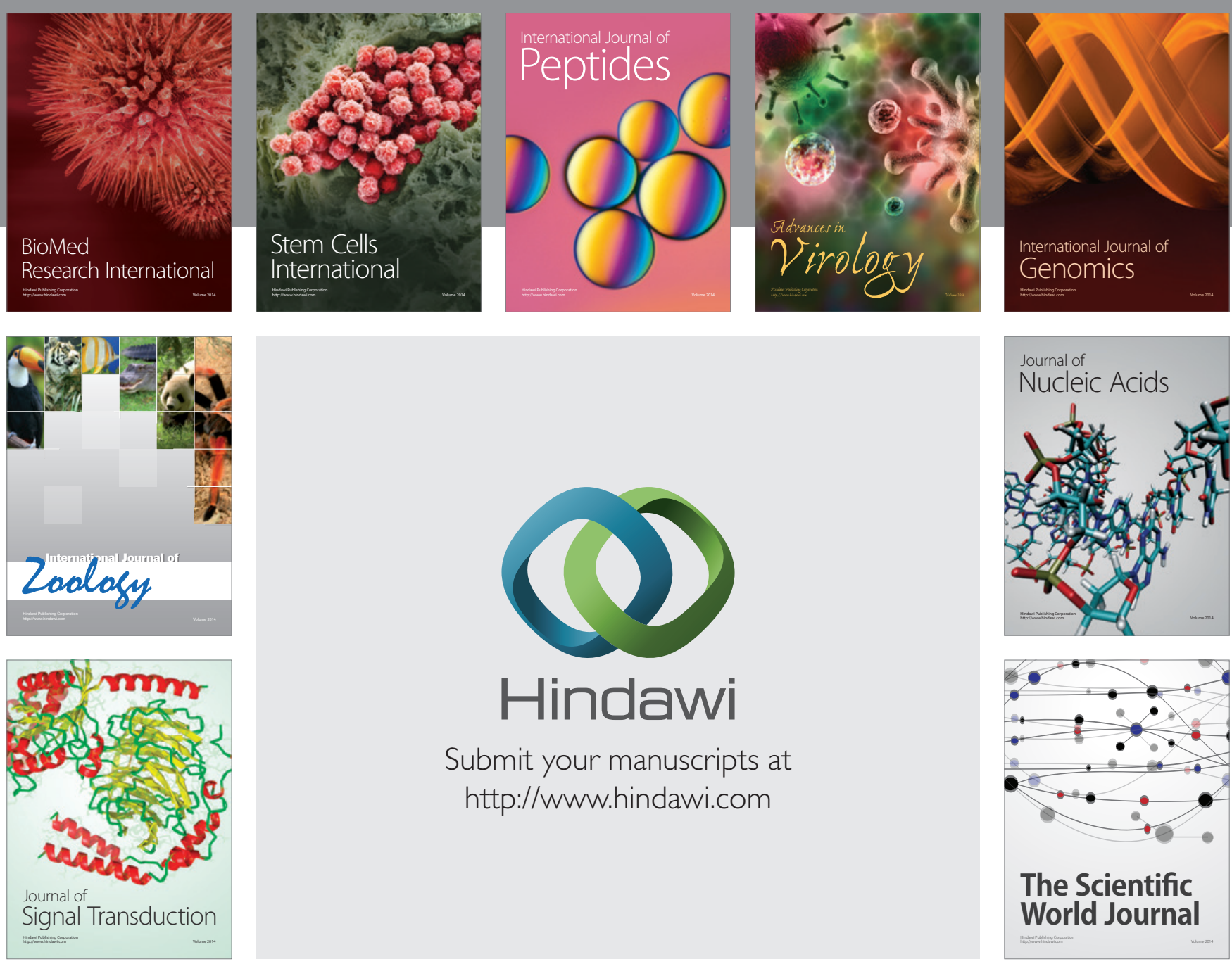

Submit your manuscripts at

http://www.hindawi.com
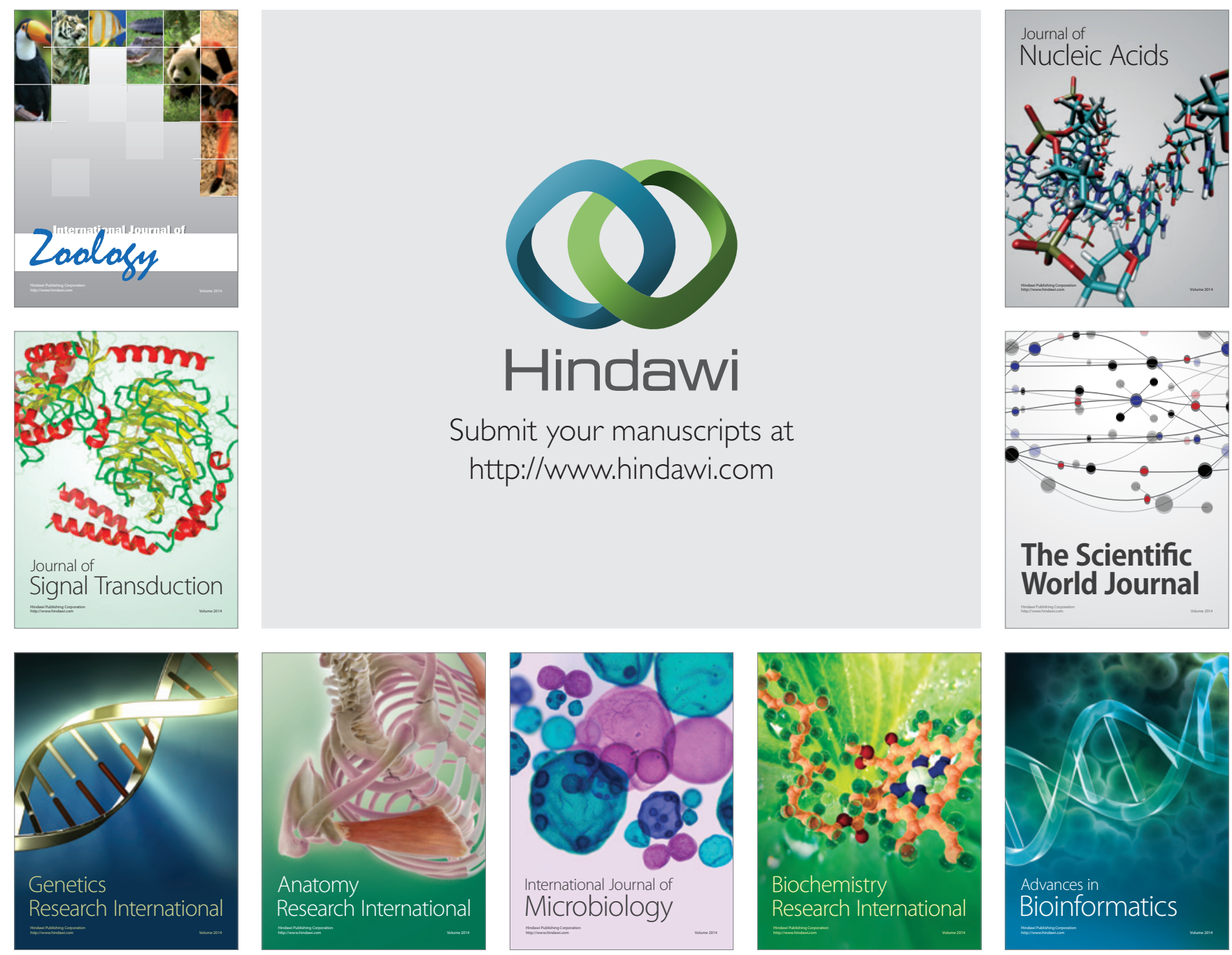

The Scientific World Journal
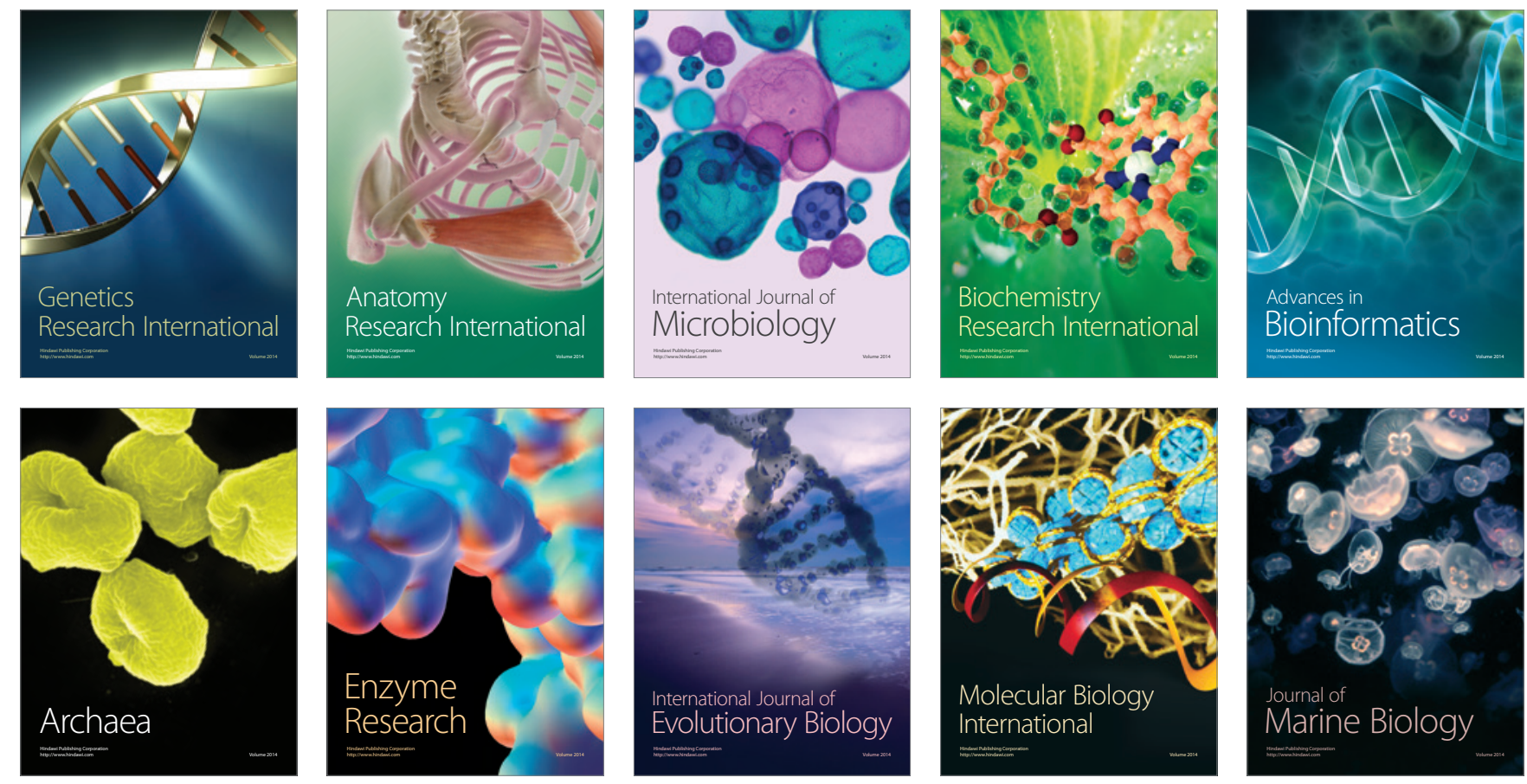